\title{
Physical and mechanical properties of edible films made from non-exportable Ecuadorian bananas
}

\author{
Propriedades físicas e mecânicas de filmes comestíveis feitos de bananas equatorianas não \\ exportáveis
}

\author{
Juliana Criollo-Feijóo*, Carlos Alberto García-González, José Humberto Ayala-Armijos, Edison Omar \\ Martínez-Mora, Fabián Patricio Cuenca-Mayorga
}

Facultad de Ciencias Químicas y de la Salud, Universidad Técnica de Machala, El Oro, Ecuador. * Author for correspondence: jlcriollo_est@utmachala.edu.ec

Submission: 20/01/2020 / Acceptance: 19/09/2020

\begin{abstract}
This study set out to determine the physical and mechanical properties of edible films made from native starch extracted from non-exportable Ecuadorian bananas (Musa sapientum L.). The following treatments were applied: $0.5 \%$ starch $-0.25 \%$ glucose $\left(T_{1}\right), 0.5 \%$ starch $-0.5 \%$ glucose $\left(T_{2}\right), 1 \%$ starch $-0.25 \%$ glucose $\left(T_{3}\right)$, and $1 \%$ starch $-0.5 \%$ glucose $\left(T_{4}\right)$. Variables such as physicochemical properties, amylose content, maximum gelation temperature, and the morphology of native starch granules were assessed. Variables in the film, such as thickness, opacity, film solubility, and tensile strength, were also measured. The fruit used in this study was composed of $88.55 \%$ starch (dry basis, $15.35 \%$ amylose). The starch granules had a dominant ovoid morphology with an average diameter of 25-30 $\mu \mathrm{m}$. The peak gelatinization temperature was $73.80{ }^{\circ} \mathrm{C}$. The maximum value for viscosity was $3,836 \mathrm{cP}$ at $86.8{ }^{\circ} \mathrm{C}$. Films that presented good malleability, thickness, transparency, tensile strength, and low solubility were obtained from $\mathrm{T}_{4}$, which turned out to be the best treatment.
\end{abstract}

KEYWORDS: tropical fruit, biopolymers, food coating, mechanical properties.

\section{RESUMO}

O objetivo do presente trabalho foi determinar propriedades físicas e mecânicas em filmes comestíveis obtidos a partir de amido nativo de banana equatoriana não exportada (Musa sapientum L.). Os tratamentos utilizados foram: $0,5 \%$ de amido $-0,25 \%$ de glicose (T1), $0,5 \%$ de amido - $0,5 \%$ de glicose (T2), $1 \%$ de amido - $0,25 \%$ de glicose (T3) e $1 \%$ de amido - $0,5 \%$ de glicose (T4). Foram determinadas variáveis como características físico-químicas, teor de amilose, temperatura de gelatinização máxima, morfologia dos grânulos de amido nativo. Foram obtidas variáveis em filmes como espessura, opacidade, solubilidade do filme. E a resistência à tração (por texturometria) foi medida. Os frutos utilizados nesta pesquisa apresentaram $88,55 \%$ de amido (base seca; amilose representou $15,35 \%$ do mencionado). A morfologia dominante encontrada nos grânulos de amido era ovóide e 25-30 $\mu \mathrm{m}$ de diâmetro médio. A temperatura máxima de gelatinização foi de $73,80^{\circ} \mathrm{C}$. O valor máximo de viscosidade ocorrido foi de $3.836 \mathrm{cP}$ a $86,8^{\circ} \mathrm{C}$. Filmes com boa maleabilidade, espessura, transparência, resistência à tração e baixa solubilidade foram obtidos de T4, tornando-se o melhor tratamento.

PALAVRAS-CHAVE: frutas tropicais, biopolímeros, revestimento de alimentos, caracterização mecânica.

One of the main exporting commodities in Ecuador is the banana (Musa sapientum) of the Cavendish variety. Exportable Cavendish banana berries must meet quality demands (e.g., $18 \mathrm{~cm}$ in length, $39-46 \mathrm{~mm}$ in diameter); however, nearly $30 \%$ of banana production does not meet these criteria (RAMÍREZ NIETO \& GUEVARA 2012). The biochemical compounds present in this banana may be a source for the production of biodegradable polymers. Biodegradable polymers are an alternative to synthetic materials for food packaging, as biopackaging enhances handling, food quality, and shelf life and does not entail the environmental issues related to synthetic packaging (DE LÉIS et al. 2017, TÓTH \& HALÁSZ 2019). Nonetheless, traditional packaging methods are still preferred due to their lower costs and impermeability. The functional properties and renewability of biopolymers and the availability of sources of extraction enable 
the production of edible films (CAO et al. 2018) intended for wrapping food products without affecting food integrity, i.e., physical, mechanical, chemical, and biochemical factors (ZINK et al. 2016).

Biopolymers extracted from plant sources are an alternative to conventional packaging materials. Chitosan, cellulose, proteins, lipids, starch, etc., have been identified as sources of biopolymers (EMBUSCADO \& HUBER 2009). Starch is an abundant, edible, biodegradable, and inexpensive polymer (BERTUZZI et al. 2007). Its starch structure is composed of granules consisting of amylose and amylopectin molecules (MATIGNON \& TECANTE 2017). Gelatinization, retrogradation, and crystallization are chemical processes in starch which occur under certain conditions. Retrogradation occurs when molecular interactions take place as the temperature of a gelatinized starch suspension decreases. Amylose controls the doublehelicoidal associations of 40 - 70 glucose units, whereas amylopectin crystallization occurs when short outer branches associate themselves (DE BARROS MESQUITA et al. 2016). The enzyme activity of amylose affects gelatinization and retrogradation (JYOTHI et al. 2011). The amount of starch extracted from banana fruit depends on extraction methods, its variety, and ripening index (HOYOS-LEYVA et al. 2015). The morphology of starch granules is related to the amyloplasts' composition and their natural conditions (DE BARROS MESQUITA et al. 2016). After reaching the peak temperature of gelatinization, unstable gel conditions occur due to the presence of larger granules. Because of the formation of a matrix with a higher starch content per area, the high amylose content and low fat content may improve tensile strength (VARGAS et al. 2017).

Given its glycosidic linear domain (a 1-4), amylose content is higher in cereal starch, resulting in films with greater tensile strength. As for techniques to determine starch's morphology, swelling power, water absorption, amylose leaching, and retrogradation, Scanning Electron Microscopy (SEM) requires samples to be dried for high-resolution photographs. Immobilization from the aqueous phase allows for imaging when water removal is not practical or when the matrix may be altered through drying (MATIGNON \& TECANTE 2017). The non-conductive nature of starch may be minimized with gold or platinum coating (OLMEDILLAALONSO et al. 2010).

Edible films are obtained after solubilization, dispersion, or emulsification of a polymer in a medium (water, ethanol, organic acids). Films of thermoplastic hydrocolloids, e.g., plasticized starch and proteins, are formed by extrusion or by direct application at a high temperature while still elastic. The chemical, physical, mechanical, and rheological properties of films depend on the material used, manufacturing techniques, and application methods. There is evidence that the protective characteristics and functional properties in biofilms improve with the incorporation of food-grade additives, e.g. plasticizers, antibiotics, antioxidants, and flavorings (GUILBERT et al. 1995).

This study aimed to assess the physical and mechanical properties in edible films made from the native starch of non-exportable banana fruit and glucose (plasticizer) so as to determine their potential use and further applications.

Non-exportable banana berries were harvested from farms located nearby Machala, Ecuador, while they were still unripe. The berries were stored below the local average room temperature of $20^{\circ} \mathrm{C}$ in an airtight, dark area for 1 - 2 weeks, as the early ripening stages began. Glucose (D-(+)-Glucose anhydrous for biochemistry reagent (Merck KGaA, Darmstadt, Germany) and fresh water bottles were purchased in local shops.

Starch was obtained based on the techniques described by BELLO-PÉREZ et al. (2002) (wet ground method). The peels were removed from the flesh. The flesh of each berry was cut into slices that were around $1 \mathrm{~cm}$ in thickness. The slices were soaked in a $2 \%$ ascorbic acid solution $(\mathrm{m} / \mathrm{v})$ to prevent browning. After 60 minutes, the soaked slices were put into a blender (Fleetwood by Skymsem LAR-15/25L, Skyfood Equipment LLC., North Miami, FL, United States) at 27,000 rpm for 3 minutes. The resulting slurry was sifted consecutively through mesh sizes of $0.841,0.420,0.149$, and $0.074 \mathrm{~mm}$. The residue left on each sieve was washed with water until any apparent starch residue had been removed. The resulting lixiviated liquid was set aside for 4 hours to allow the sediments to settle, and the aqueous phase was removed. The starchy sediments were dried in a laboratory oven (Memmert $\mathrm{GmbH}+\mathrm{Co}$. KG, Schwabach, Germany) at $57^{\circ} \mathrm{C}$ for 12 hours.

Water, protein, crude fat, ash, and carbohydrate content were measured after applying AOAC methods (AOAC 2003, TIRADO et al. 2015). To measure the apparent amylose, $0.1 \mathrm{~g}$ starch was dissolved in dimethyl sulfoxide (Merck KGaA, Darmstadt, Germany) at $85{ }^{\circ} \mathrm{C}$ for 15 minutes. Once dissolved, the solution was diluted in distilled water to $25 \mathrm{ml}$. A $1 \mathrm{ml}$ aliquot of this solution was diluted in distilled water to $50 \mathrm{ml}$, and $5 \mathrm{ml}$ of an iodine solution $(0.0025 \mathrm{~mol} / \mathrm{L})$ in potassium iodide $(0.0065 \mathrm{~mol} / \mathrm{L})$ were added and then mixed. The absorbance of the samples was read in the Cary 50 UV-Vis spectrophotometer (Agilent Technologies, Santa Clara, United States) at $600 \mathrm{~nm}$ (HOOVER \& RATNAYAKE 2002). 
The morphology of the starch granules in the samples was observed with the JSM-6300 scanning electron microscope (SEMTech Solutions, Inc. North Billerica, United States) in the high vacuum mode at X1500 magnification. Starch samples were coated with a thin gold film to improve conductivity, i.e., to enhance image resolution.

Differential scanning calorimetry (DSC) was used to measure the peak gelatinization temperature for starch (SINGH \& SINGH 2001): $2 \mathrm{mg}$ of starch were weighed in an aluminum sample holder. Water was added at a ratio of 1:3 w/v (starch/water). The sample holders were sealed and placed in the DSC Q2000 (TA, New Castle, United States) and underwent temperatures ranging from $30^{\circ} \mathrm{C}$ to $120^{\circ} \mathrm{C}$ at a thermal speed of $10^{\circ} \mathrm{C}$ per minute. An empty sample holder was used to set a value for the blank. Initial temperature $\left(T_{i}\right)$, peak temperature $\left(T_{p}\right)$, final temperature $\left(T_{f}\right)$, and gelatinization enthalpy $\left(\Delta_{H}\right)$ were derived from the thermograms generated.

Starch samples were weighed and placed in an aluminum container attached to a viscometer (RVA 4500 , Perten, Sweden). Distilled water was added until the weight reached $28 \mathrm{~g}$. A suspension of $6 \%$ starch was heated from $50{ }^{\circ} \mathrm{C}$ to $92{ }^{\circ} \mathrm{C}$ at a constant thermal speed of $1.5^{\circ} \mathrm{C}$ per min with constant stirring at 160 rpm. The sample was maintained at the peak temperature for 10 minutes. Afterwards, the temperature was dropped to $50^{\circ} \mathrm{C}$. Maximum viscosity was calculated at $92^{\circ} \mathrm{C}$ based on the resulting amylograms.

The percentages of starch used in this experiment were $0.5 \%$ and $1 \%$, and for plasticization, the percentages of glucose were 0.25 and $0.5 \%$. A $100 \mathrm{~g}$ solution was prepared for each resulting combination of factors, i.e., treatments (Table 1). The solutions were heated in a magnetic stirrer (Thermo Fisher Scientific, Pittsburgh, United States) at $700 \mathrm{rpm}$ until gelatinization. For plasticization, glucose was added when the temperature shifted to $40{ }^{\circ} \mathrm{C}$. The Ultra-Turrax (IKA ${ }^{\circledR}-$ Works, Inc., Wilmington, United States) dispersion mixer was used to homogenize the treated solution at $11000 \mathrm{rpm}$ for 30 seconds. Subsequently, $20 \mathrm{ml}$ of the resulting film-forming solutions (around $0.2 \mathrm{~cm}$ of thickness) were poured into Petri dishes with an inner diameter of $8 \mathrm{~cm}$ and left to dry for 48 hours at room temperature $\left(25^{\circ} \mathrm{C}\right)$ (SANTACRUZ et al. 2015), whereupon the films were removed from the Petri dishes.

Table 1. Treatments used to prepare the films.

\begin{tabular}{lccc}
\hline Treatment & Banana starch $(\mathrm{g})$ & Glucose $(\mathrm{g})$ & Water $(\mathrm{g})$ \\
\hline $\mathrm{T}_{1}$ & 0.50 & 0.25 & 99.25 \\
$\mathrm{~T}_{2}$ & 0.50 & 0.50 & 99.00 \\
$\mathrm{~T}_{3}$ & 1 & 0.25 & 98.75 \\
$\mathrm{~T}_{4}$ & 1 & 0,50 & 98.50 \\
\hline
\end{tabular}

Small film pieces were placed in spectrophotometer cells, and absorbance was measured at $620 \mathrm{~nm}$ in the Jenway VIS spectrophotometer (Cole Parmer, Staffordshire, United Kingdom). Low opacity values corresponded to a high degree of transparency (GÓMEZ-ESTACA et al. 2009). Opacity was calculated by the following equation:

$$
\text { opacity }=\frac{A b s_{620}}{X}
$$

where

$\mathrm{Abs}_{620}=$ absorbance value detected at $620 \mathrm{~nm}$,

$X=$ film thickness (in $\mathrm{mm}$ ).

To measure solubility, film pieces of $3 \times 1 \mathrm{~cm}$ were dried at $100{ }^{\circ} \mathrm{C}$ to constant weight. Dried films were submersed in $50 \mathrm{ml}$ of distilled water in a beaker and then agitated at $100 \mathrm{rpm}$ in an orbital stirrer (MRC, Cologne, Germany) at room temperature for 24 hours. Visible undissolved film parts were separated from the solution and dried in an oven at $100^{\circ} \mathrm{C}$ for 24 hours. Dried undissolved material was weighed (COLLA et al. 2006). The films' tensile strength was measured with a textometer (Shimadzu Co., Kyoto, Japan) and the Trapezium $X^{\circledR}$ software (Shimadzu Co., Kyoto, Japan). A micrometer (Mitutoyo Co., Kawasaki, Japan) was used to measure thickness.

A factorial design was applied to find whether differences arose among treatments; the experimental factors were starch concentration and plasticizer concentration. The dependent variables were thickness, solubility, opacity, and tensile strength. Tukey's test was used to find significant differences among treatments ( $\leq$ 0.05). IBM SPSS Statistics 20 (IBM, Armonk, New York) was used to process all statistical data.

The native starch content obtained from the banana fruit was $88.55 \%$ (isolated banana starch, dry Rev. Ciênc. Agrovet., Lages, SC, Brasil (ISSN 2238-1171) 
basis). This value was consistent with and slightly above those reported for other banana cultivars, such as Gros Michel (83.74\%), Guayabo (82\%), and Hartón (85\%) (ÁLVAREZ BARRETO 2014, CHÁVEZ-SALAZAR et al. 2017). The amylose content in native banana starch was $15.35 \%$ (dry basis); amylopectin content was $84.65 \%$. The physicochemical composition of native banana starch is shown in Table 2.

Table 2. Physicochemical composition of native banana starch.

\begin{tabular}{lc}
\hline \multicolumn{1}{c}{ Compound } & $\%$ \\
\hline Moisture (water content) & $9.41 \pm 0.7$ \\
Fat & $0.47 \pm 0.05$ \\
Protein & $0.89 \pm 0.06$ \\
Ash & $0.68 \pm 0.03$ \\
Total Starch & $88.55 \pm 0.19$ \\
\hline
\end{tabular}

Average results $n=3, \pm$ standard deviation.

According to the SEM results, the granules had an ovoid shape and smooth surfaces with a diameter of 25-30 $\mu \mathrm{m}$, which is consistent with MARTíNEZ-MORA (2015) and MONTOYA LÓPEZ et al. (2014), who reported an ovoid shape and a diameter of $28 \mu \mathrm{m}$ for exportable Cavendish banana fruit. Figure 1 depicts a SEM image of banana starch sample and the DSC results for a $6 \%$ starch solution. The initial gelatinization temperature $\left(T_{i}\right)$ was $70.80^{\circ} \mathrm{C}$, and the peak temperature $\left(T_{P}\right)$ was $73.8^{\circ} \mathrm{C}$. MONTOYA LÓPEZ et al. (2014) reported a peak temperature of $74.5{ }^{\circ} \mathrm{C}$. The resulting peak curve went downward as the final temperature $\left(\mathrm{T}_{\mathrm{f}}\right)$ reached $83.68{ }^{\circ} \mathrm{C}$. The gel presented a stable state. A gelatinization enthalpy $\left(\Delta_{\mathrm{Hp}}\right)$ of $14.02 \mathrm{~J} / \mathrm{g}$ was required to complete the process, which was lower than those reported for Gros Michel starch at $44.62 \mathrm{~J} / \mathrm{g}$ (MONTOYA LÓPEZ et al. 2014).

Maximum viscosity (Vmax) was $3,836 \mathrm{cP}$ at $86.8^{\circ} \mathrm{C}$, which is higher than the value of 2,400 reported for dessert bananas, including Cavendish (DUFOUR et al. 2009). Cold paste viscosity (CPV) decreased to $2,087.5 \mathrm{cP}$ at $50^{\circ} \mathrm{C}$. The values for hot paste viscosity (HPV) and viscosity breakdown (VB) were $1,995.5 \mathrm{cP}$ and $1,840.5 \mathrm{cP}$, respectively. It is assumed that these values were influenced by the concentration of starch. Figure 1 shows the Cavendish banana starch granule at x1500 magnification, the DSC thermogram, and the native banana starch pasting profile.
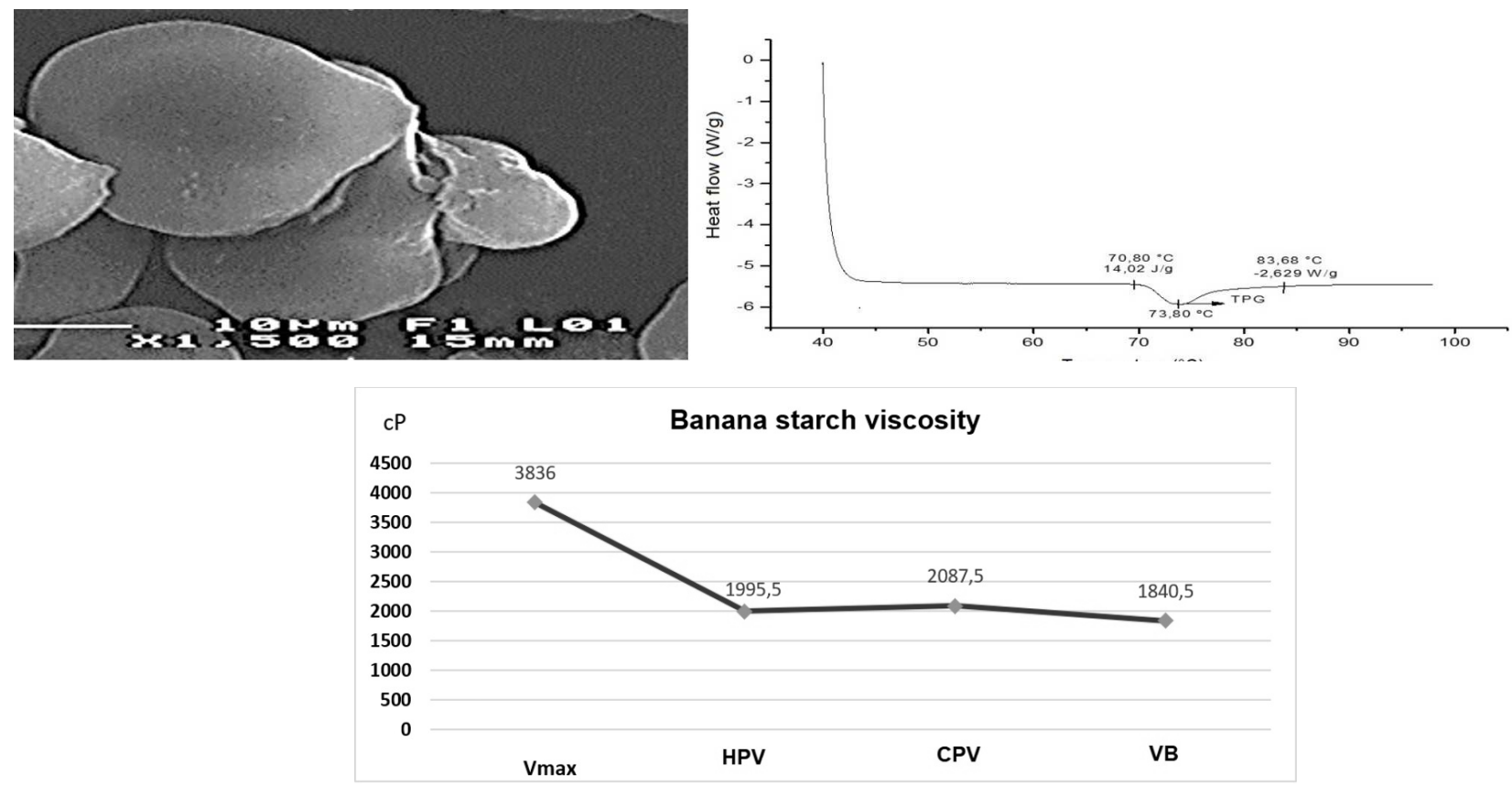

Figure 1. Cavendish banana starch granule at x1500 magnification, DSC thermogram, and native banana starch pasting profile.

The results indicated that the films' thickness was directly proportional to the percentage of starch. The highest opacity, $2.28 \mathrm{~mm}^{-1}$, was found in $\mathrm{T}_{2}$, while the lowest, $1.73 \mathrm{~mm}^{-1}$, was in $\mathrm{T}_{3}$. Therefore, a higher concentration of starch corresponds to lower opacity in edible films. Solubility was $21.5 \%-41.01 \%$, and the 
lowest values were detected in $T_{1}$, similar to results reported for corn and chia starch films (around 35\%) (VARGAS et al. 2017, NOURADDINI et al. 2018). Tensile strength was $8.20-11.47 \mathrm{mPa}$. Table 3 illustrates the physical properties of the films.

Table 3. Films' physical and mechanical properties.

\begin{tabular}{ccccc}
\hline Treatments & $\begin{array}{c}\text { Thickness } \\
(\mathrm{mm})\end{array}$ & $\begin{array}{c}\text { Opacity } \\
\left(\mathrm{mm}^{-1}\right)\end{array}$ & $\begin{array}{c}\text { Solubility } \\
(\%)\end{array}$ & $\begin{array}{c}\text { Tensile strength } \\
(\mathrm{MPa})\end{array}$ \\
\hline $\mathrm{T}_{1}$ & $0.019 \pm 0.0003^{\mathrm{a}}$ & $2.14 \pm 0.002^{\mathrm{a}}$ & $21.5 \pm 0.48^{\mathrm{a}}$ & $8.20 \pm 0.03^{\mathrm{a}}$ \\
$\mathrm{T}_{2}$ & $0.020 \pm 0.001^{\mathrm{a}}$ & $2.28 \pm 0.008^{\mathrm{b}}$ & $26.5 \pm 1.24^{\mathrm{b}}$ & $10.23 \pm 0.09^{\mathrm{b}}$ \\
$\mathrm{T}_{3}$ & $0.024 \pm 0.001^{\mathrm{a}}$ & $1.73 \pm 0.003^{\mathrm{c}}$ & $35.6 \pm 1.35^{\mathrm{c}}$ & $10.51 \pm 1.1^{\mathrm{c}}$ \\
$\mathrm{T}_{4}$ & $0.025 \pm 0.001^{\mathrm{a}}$ & $1.76 \pm 0.003^{\mathrm{d}}$ & $41.01 \pm 1.41^{\mathrm{d}}$ & $11.47 \pm 0.08^{\mathrm{d}}$ \\
\hline
\end{tabular}

$\mathrm{n}=3$. \pm Standard deviation. Means followed by the same letters in a column do not differ significantly by the post hoc test $(p<0.05)$.

Edible films obtained from the native starch of Cavendish banana fruit presented good malleability, thickness, transparency, tensile strength, and low solubility. $\mathrm{T}_{4}(1 \%$ starch, $0.5 \%$ glucose) was the best treatment as it had higher yields (tensile strength, $11.47 \pm 0.08 \mathrm{MPa}$; solubility, $41.01 \pm 1.41 \%$ ). Starch concentration and plasticizers affected the films' physical and mechanical properties.

\section{ACKNOWLEDGEMENTS}

The authors wish to thank the food technology laboratory staffs at ULEAM (Manta, Ecuador) and at UAEH (Pachuca de Soto, Mexico).

\section{REFERENCES}

ÁLVAREZ BARRETO Cl. 2014. Propiedades reológicas de frutos y masas de plátanos procesados por cocción y su relación con la modificación del almidón. Tese. (Doutorado em Engenheria Alimentar). Cali: Universidad del Valle. $118 \mathrm{p}$.

AOAC. 2003. AOAC methods to asses content of moisture, fiber, ashes, fat, and protein. Rockville: AOAC. Available at: https://www.aoac.org/scientific-solutions/standards-and-official-methods/. Access on: April 14. 2019.

BELLO-PÉREZ L et al. 2002. Chemical and functional properties of modified starch from banana Musa paradisiaca L. (Var. Macho). Agrociencia 36: 169-180.

BERTUZZI MA et al. 2007. Water vapor permeability of edible starch-based films. Journal of Food Engineering 80: $972-$ 978.

CAO L et al. 2018. Developing a green and edible film from Cassia gum: The effects of glycerol and sorbitol. Journal of Cleaner Production 175: 276-282.

CHÁVEZ-SALAZAR A et al. 2017. Isolation and partial characterization of starch from banana cultivars grown in Colombia. International Journal of Biological Macromolecules 98: 240-246.

COLLA E et al. 2006. Amaranthus cruentus flour edible films: Influence of stearic acid addition, plasticizer concentration, and emulsion stirring speed on water vapor permeability and mechanical properties. Journal of Agricultural and Food Chemistry 54: 6645-6653.

DE BARROS MESQUITA C et al. 2016. Characterization of banana starches obtained from cultivars grown in Brazil. International Journal of Biological Macromolecules 89: 632-639.

DE LÉIS C et al. 2017. Environmental and energy analysis of biopolymer film based on cassava starch in Brazil. Journal of Cleaner Production 143: 76-89.

DUFOUR D et al. 2009. Differentiation between cooking bananas and dessert bananas. 2. thermal and functional characterization of cultivated Colombian musaceae (Musa sp.). Journal of Agricultural and Food Chemistry 57: 78707876.

EMBUSCADO M \& HUBER KC. 2009. Edible Films and Coatings for Food Applications. Berlín: Springer Science + Business Media. p. 135-168.

GÓMEZ-ESTACA J et al. 2009. Incorporation of antioxidant borage extract into edible films based on sole skin gelatin or a commercial fish gelatin. Journal of Food Engineering 92: 78-85.

GUILBERT S et al. 1995. Technology and applications of edible protective films. Packaging Technology and Science 8: 339-346.

HOOVER R \& RATNAYAKE WS. 2002. Starch characteristics of black bean, chick pea, lentil, navy bean and pinto bean cultivars grown in Canada. Food Chemistry 78: 489-498.

HOYOS-LEYVA $\mathrm{J}$ et al. 2015. Optimising the heat moisture treatment of Morado banana starch by response surface analysis. Starch 67: 1026-1034.

JYOTHI AN et al. 2011. Hydrothermal modifications of tropical tuber starches - Effect of ANN on the physicochemical, rheological and gelatinization characteristics. Starch 63: 536-549.

MARTÍNEZ-MORA EO. 2015. Caracterización morfológica y contenido de almidón resistente y disponible en bananos 
(Musa sapientum) exportables del Ecuador. Spanish Journal of Human Nutrition and Dietetics 19: 153-159.

MATIGNON A \& TECANTE A. 2017. Starch retrogradation: From starch components to cereal products. Food Hydrocolloids 68: 43-52.

MONTOYA LÓPEZ $\mathrm{J}$ et al. 2014. Caracterización de harina y almidón de frutos de banano Gros Michel (Musa acuminata AAA). Acta Agronomica 64: 11-21.

NOURADDINI M et al. 2018. Development and characterization of edible films based on eggplant flour and corn starch. International Journal of Biological Macromolecules 120: 1639-1645.

OLMEDILLA-ALONSO B et al. 2010. Papel de las leguminosas en la alimentación actual. Actividad Dietetica 14: $72-76$.

RAMÍREZ NIETO CJ \& GUEVARA SS. 2012. Banano rechazado para exportación en Ecuador: propuesta de creación de valor para lograr su introducción al mercado internacional. Dissertação (Mestrado em Administração de Empresas). Guayaquil. UPS. 229p.

SANTACRUZ S et al. 2015. Edible films based on starch and chitosan. Effect of starch source and concentration, plasticizer, surfactant's hydrophobic tail and mechanical treatment. Food Hydrocolloids 49: 89-94.

SINGH J \& SINGH N. 2001. Studies on the morphological, thermal and rheological properties of starch separated from some Indian potato cultivars. Food Chemistry 75: 67-77.

TIRADO DF et al. 2015. Estudio comparativo de métodos empleados para la determinación de humedad de varias matrices alimentarias. Informacion Tecnologica 26: 3-10.

TÓTH A \& HALÁSZ K. 2019. Characterization of edible biocomposite films directly prepared from psyllium seed husk and husk flour. Food Packaging and Shelf Life 20: 100299.

VARGAS C et al. 2017. Comparative study on the properties of films based on red rice (Oryza glaberrima) flour and starch. Food Hydrocolloids 65: 96-106.

ZINK J et al. 2016. Physical, chemical and biochemical modifications of protein-based films and coatings: An extensive review. International Journal of Molecular Sciences 17: 1376. 